\section{Influence of phosphate layer on adhesion properties between a steel surface and an organic coating}

Rudarsko-geološko-naftni zbornik

(The Mining-Geology-Petroleum Engineering Bulletin) UDC: $62-9$

DOI: 10.17794/rgn.2022.1.2

Preliminary communication

\author{
Marina Samardžija'; Vesna Alar²; Fedor Aljinović'; Frankica Kapor ${ }^{1}$ \\ ${ }^{1}$ University of Zagreb, Faculty of Mining-Geology-Petroleum Engineering, Pierottijeva 6, Department of Chemistry, Zagreb, Croatia \\ ${ }^{2}$ University of Zagreb, Faculty of Mechanical Engineering and Naval Architecture, St. Ivana Lučića 5, Department of Welded Structures, \\ Zagreb, Croatia
}

\begin{abstract}
In this paper, tests of some physico-chemical properties of protective epoxy coating on non-alloy structural steel grade type S235JRG2 have been carried out. This is a significant construction material whose use is remarkably important for many steel products, such as $\mathrm{H}$ beams, I beams, transmission towers, steel pipes, etc. Coatings represent one of the ways to protect metal from corrosion. The properties of coating thickness, hardness, gloss, and adhesion were investigated. The same properties were tested by exposing the sample non-alloy steel plates to the corrosive conditions of salt and a humid chamber and seawater. Part of the samples were immersed in a phosphate solution prior to the application of the coating to further investigate the effects of phosphatization on the properties of the coating. After exposure of the plates to the humidity chamber conditions, no traces of corrosion products, cracking or peeling of the coating were found on the surfaces. The plates tested in the sea water and salt chamber showed a minor damage on protective coating. The traitability properties were tested by the Pull off Adhesion test. The force in the pull off adhesion test shows a lower value for unphosphated samples than for phosphated ones.
\end{abstract}

Keywords:

corrosion; non-alloy steel grade; phosphatizing process; epoxy coating

\section{Introduction}

Iron and iron alloys, including non-alloyed ones, are popular in the design and construction of engineering structures and piping applications (Ubong and Mazen, 2014; Morozov et al., 2019). Unfortunately, the mechanical features of non-alloy steel, including surface hardness, are not outstanding, and their use is restricted in certain applications (Naeem, et al., 2017). However, the environments to which they are deployed cause not only damage, but also produce great waste of resources and economic losses (Ubong and Mazen, 2014; Wang et al., 2019). Steel is very sensitive to different forms of corrosion when operating in the harsh environments, common in Oil\&Gas application, but appropriate corrosion control can help prevent many potential disasters that can cause serious issues, including loss of life, negative social impacts, and water resource and environmental pollution (Morozov et al., 2019; Finšar and Jackson, 2014).

The application of an organic coating on steel is one promising strategy for extending its service life. Organic coatings provide a passive physical barrier between the

Corresponding author: Marina Samardžija

marina.samardzija@rgn.hr corrosive environment and the metal surface (Ramezanzadeh et al., 2020). Among these protective properties of organic coating, epoxy coating is the most broadly applied material for industrial and engineering applications due to its advantages of good protection effect, simple method, good adhesion to metals, high corrosion resistance and low cost (Khodaei et al. 2019, Wang et al., 2019, Ramazanzdeh et al., 2019). These coatings include an inner primer layer loaded with anti-corrosion pigments (Morozov et al., 2019). The topcoat is responsible for environmental resistance and different functional and aesthetic requirements. An intermediate coat is sometimes needed in order to increase the total coating thickness and enhance the barrier effect against highly corrosive environments (Zhang et al., 2018). However, water, oxygen and corrosive ions can diffuse into the epoxy resin through coating defects derived from improper curing, low cross-link density and local shrinkage resulting in coating delamination (adhesion loss) and substrate corrosion (Rahamani et al., 2020). To enhance corrosion protection, surface treatment and various coatings have been suggested and applied (Mei et al., 2019).

A thin phosphate coating was used, with the aim to investigate its influence as an adhesion promoter (Bajat et al. 2008). The phosphatizing process involves a topo- 
chemical reaction between a primary phosphate solution with a metal surface, promoting the precipitation of an insoluble tertiary salt (Macías et al., 2013). This process is the most common type of chemical treatment which has been primarily used as a pretreatment of surfaces to protect them against underpaint corrosion; to pretreat surfaces for metal forming operations, such as cold extrusion, and to improve corrosion resistance by providing a good base for waxes and rust-preventive oils (Gang et al., 1997). Due to its economic price, speed of operation and ability to provide excellent corrosion resistance, wear resistance, adhesion, and lubricative properties, it plays a significant role in the automobile, processing, and appliance industries (Jegannathan et al., 2006). Metal coatings also provide good benefits against early rusting but decrease the grade of the steel in practical application (Jiang and Cheng, 2019). An epoxy coating can protect the metal substrate by releasing inhibiting chemicals from the pigment to form a strong passive or barrier layer that inhibits the corrosive medium contact with the metal substrate (Yongsheng et. al, 2013). So far, the classical alternative, zinc phosphate, has been widely used (Naderi and Attar, 2009).

\section{Experimental}

\subsection{Materials}

The materials used in this study include epoxy coating and polyurethane provided by Midi Ltd. Croatia. S235JRG2 non-alloy steel grade was investigated. The chemical composition of the non-alloy steel grade is shown in Table 1.

Table 1: The chemical composition of samples

\begin{tabular}{|l|c|c|c|c|c|c|c|}
\hline Sample & $\mathbf{C}$ & $\mathbf{M n}$ & $\mathbf{P}$ & $\mathbf{S}$ & $\mathbf{C u}$ & $\mathbf{N}$ & $\mathbf{F e}$ \\
\hline$(\%)$ & 0.17 & 1.4 & 0.035 & 0.035 & 0.55 & 0.01 & balance \\
\hline
\end{tabular}

The chemical composition of steel sample was determined by optical emission 101 spectrum GDS $850 \mathrm{~A}$, LECO.

\subsection{Preparation of samples}

Common non-alloy steel S235JRG2 plates of $4 \mathrm{~mm}$ thickness were cut in pieces of $100 \times 150 \mathrm{~mm}$. The surface of samples was polished up to 1200 grid sandpapers and finally degreased by acetone. The samples were immersed in the following phosphate solution: $\mathrm{H}_{3} \mathrm{PO}_{4}(\geq$ $85.0 \%), \mathrm{ZnO}, \mathrm{HNO}_{3}, \mathrm{NaOH}$. Part of the samples were phosphated prior to the application of the coating to further investigate the effects of phosphatization on the properties of the coating. The three coatings were added to the steel samples according to Table 2.

\subsection{Characterization method}

In this paper, tests of some physical properties of protective epoxy coating on non-alloy steel type S235JRG2 have been carried out. The properties of coating thickness, hardness, gloss, and adhesion were investigated. The surface morphology of coating was observed by Scanning electron microscope (SEM) and stereo microscope (Leica at a magnification of 50x). The thickness of the coated samples was determined with a coating thickness gauge Elcometer ${ }^{\circledR}$ 355, and gloss was tested by TQC Polygloss. The specular gloss of the unphosphated and phosphated samples were determined at $20^{\circ}, 60^{\circ}$ and $85^{\circ}$ incident angle according to HRN EN ISO 2813. The gloss was measured for the initial sample and the sample which was exposed to corrosive conditions. The measurements were performed only after the samples had been dried. The adhesion strength between the epoxy coating and the substrate was characterized by the PosiTest Pull-Off Adhesion Tester according to HRN EN ISO 4624, ASTM D451 and BS EN 24624. The pulloff force was measured for the initial sample and the sample which was exposed to corrosive conditions. Elcometer Cyanoacrylate Adhesive was used for aluminium dollies with a diameter of $20 \mathrm{~mm}$, and it was dried at room temperature for $24 \mathrm{~h}$. The measurements were performed only after the samples had been dried. The hardness of the coating was determined with 14 test-pens.

The same properties were tested by exposing the sample non-alloy steel plates to corrosive conditions of the salt and humid chamber and seawater. The salt water was prepared by using $\mathrm{NaCl}$ and deionized water and stored in a $100 \mathrm{~L}$ tank. The salt chamber testing was conducted in an Ascott cabinet, model S450 (Ascott Analytical Equipment Limited, Staffordshire, UK). The humidity test was conducted according to ISO 6270-2. According to HRN EN ISO 6270-2, the samples had been in the chamber for ten days (240 hours).

The coating resistance of sea atmosphere on unphosphated and phosphated samples have been carried out. According to HRN EN ISO 9227, the samples had been in the chamber for ten days (240 hours). Before the samples were exposed to corrosive conditions, the samples were cut with a scalpel to facilitate the potential spread of corrosion. Part of the samples were phosphated prior to the

Table 2: Content of coat

\begin{tabular}{|l|l|l|l|l|}
\hline \multicolumn{2}{|l|}{} & binder & pigment & solvent \\
\hline \multirow{4}{*}{ coat } & primer coat & epoxy resin & zinc phosphate & alcohol, aromatics, hydrocarbons \\
\cline { 2 - 5 } & intermediate coat & epoxy resin & iron oxide & aromatics, glycol ether \\
\cline { 2 - 5 } & topcoat & polyurethane & iron oxide & aromatics, aromatic hydrocarbons \\
\hline
\end{tabular}


application of the coating to further investigate the effects of phosphatization on the properties of the coating.

\section{Results and discussion}

\subsection{Morphology of as prepared epoxy coatings}

The morphological structure of organic coatings was inspected by SEM and stereo microscope. Figure 1a shows the surface section morphology of the unphosphated samples. After the phosphate surface treatment, a thin layer (see Figure 1b) of phosphate was applied. As we can see from optical images of the samples, it is obvious that the organic coating had been successfully loaded onto the non-alloy steel.

The formation process of the phosphate layer on carbon steel involves an acid attack and oxidation. The main reactions were the formation of a zinc phosphate film on the metal surface and the release of hydrogen (Dagdag et all., 2018). The $\mathrm{Fe}^{2+}$ ions, which are in steel surface, do react with acid radicals $\mathrm{PO}_{4}^{3-}$. The following is the reaction (Hiromoto, 2015):

$$
3 \mathrm{Fe}+2 \mathrm{H}_{3} \mathrm{PO}_{4} \rightarrow \mathrm{Fe}_{3}\left(\mathrm{PO}_{4}\right)_{2}+3 \mathrm{H}_{2} \uparrow
$$

As a result of these reactions, the $\mathrm{pH}$ value increased and $\mathrm{Zn}\left(\mathrm{H}_{2} \mathrm{PO}\right)_{4}$, which is present in phosphate solution, decomposed to $\mathrm{Zn}_{3}\left(\mathrm{PO}_{4}\right)_{2}$. The conventional view of the phosphate process with zinc ions is that the following reactions occur (Zhang et all, 2008):

$$
\begin{aligned}
& \mathrm{H}_{3} \mathrm{PO}_{4} \leftrightarrow \mathrm{H}^{+}+\mathrm{H}_{2} \mathrm{PO}_{4}^{-} \leftrightarrow 2 \mathrm{H}^{+}+\mathrm{HPO}_{4}^{2-} \leftrightarrow 3 \mathrm{H}^{+}+\mathrm{PO}_{4}^{3-} \\
& 3 \mathrm{Zn}^{2+}+2 \mathrm{PO}_{4}^{3-}+4 \mathrm{H}_{2} \mathrm{O} \rightarrow \mathrm{Zn}_{3}\left(\mathrm{PO}_{4}\right)_{2} 4 \mathrm{H}_{2} \mathrm{O} \downarrow \\
& \text { or: } 3 \mathrm{Zn}^{2+}+2 \mathrm{H}_{2} \mathrm{PO}_{4}^{-}+2 \mathrm{H}^{+}+4 \mathrm{H}_{2} \mathrm{O}+6 \mathrm{e}^{-} \rightarrow \\
& \quad \rightarrow \mathrm{Zn}_{3}\left(\mathrm{PO}_{4}\right)_{2} \cdot 4 \mathrm{H}_{2} \mathrm{O} \downarrow+3 \mathrm{H}_{2} \uparrow
\end{aligned}
$$

On the surface of carbon steel, sparingly soluble salts of zinc (II) phosphate and iron (II) phosphate appeared.
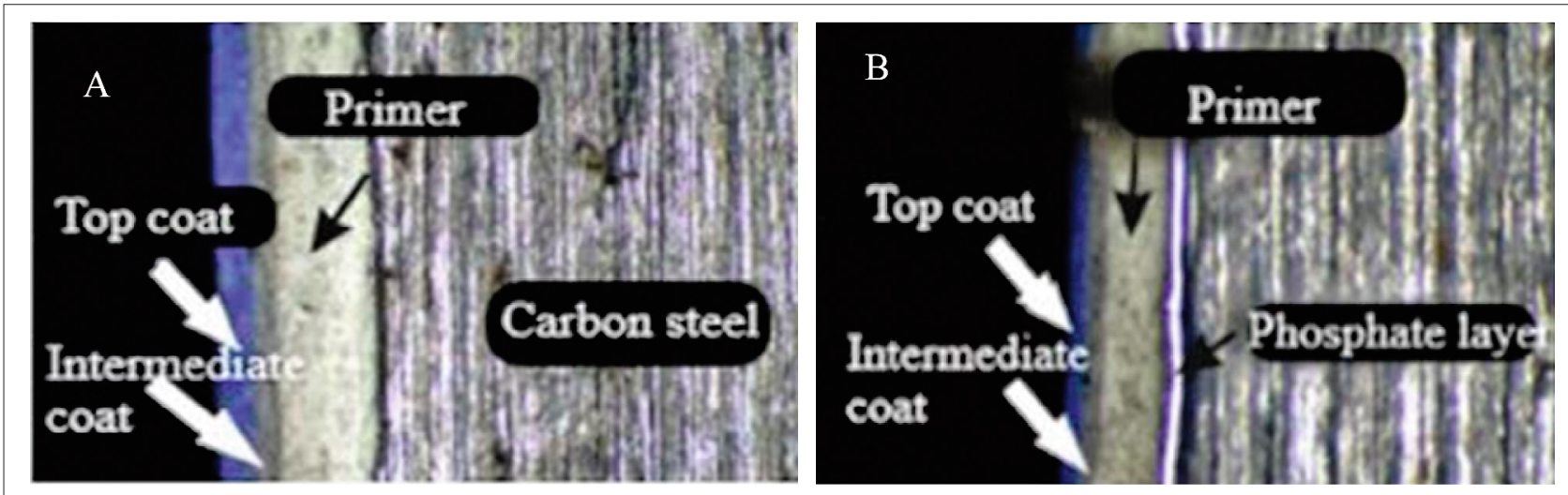

Figure 1: Optical images of the unphosphated (A) and phosphated (B) samples
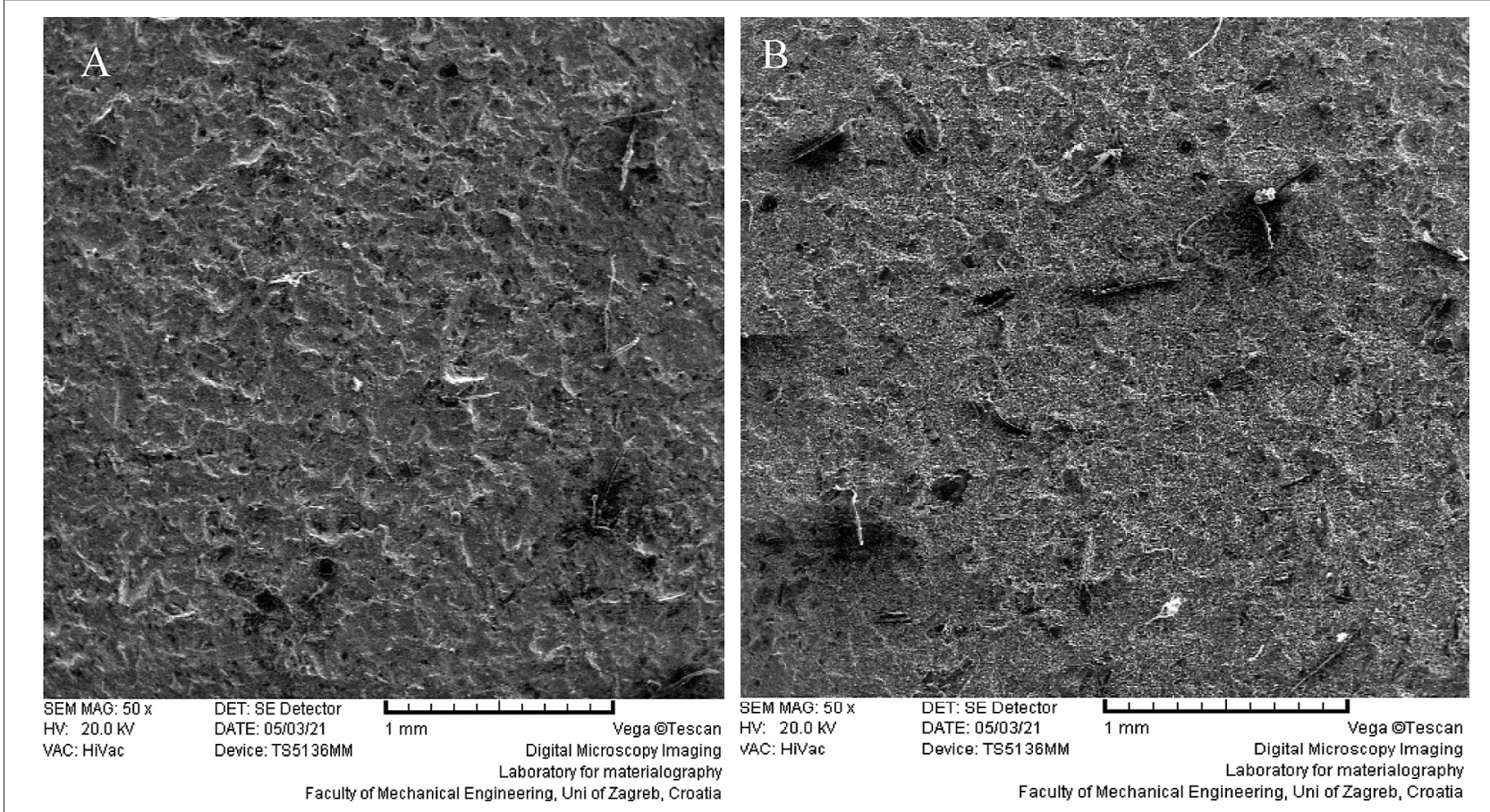

Figure 2: The morphology of: (A) bare steel and (B) phosphate steel 
The phosphate process is the method used to increase the durability of metal/epoxy system and it is a protective film in a corrosive medium. Figure 2 shows the difference between the surface morphology on bare steel (a) and phosphate steel with an epoxy and polyurethane coat (b).

It is found, from Figure 2a and Figure $\mathbf{2 b}$, that the surface of the unphosphated sample presented a relatively smoother morphology and the surface qualities of the zinc phosphate coat show good surface qualities without defects. Besides, the zinc phosphate has a homogeneous dispersion and good compatibility with the epoxy resin. The presence of zinc ion $\left(\mathrm{Zn}^{2+}\right)$ during the curing stage could be an advantage, since it behaves as a Lewis acid, that coordinates to the oxygen atom of the oxirane ring, thus making the oxirane ring more susceptible for a nucleophilic addition reaction with amine to undergo ring opening (Ming-Zhe et all., 2013). Likewise, the hydroxide ion also creates a ring opening as shown in the following chemical reaction (Reza Saeb et all., 2013):

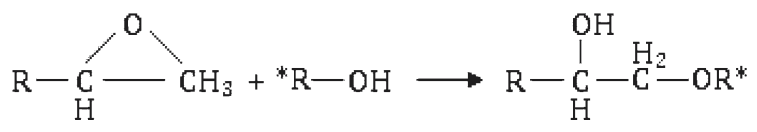

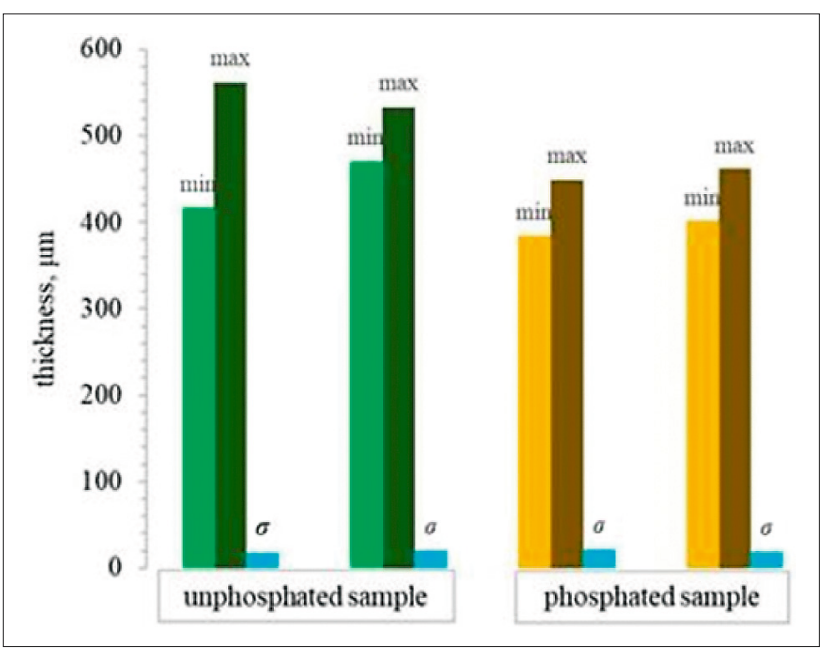

Figure 3: Minimum and maximum thickness of the coating and standard deviation for two unphosphated and two phosphate samples
The thickness of the dried coatings was maintained about $495 \mu \mathrm{m}$ for unphosphated samples, and for phosphated samples they were $424 \mu \mathrm{m}$. Figure 3 illustrates the thickness of two unphosphated and two phosphated samples that are further exposed to corrosive conditions in humidity and a salt chamber. The results from thickness show the minimum and maximum thickness of the coating do not deviate significantly, which confirms uniformly applied layers.

\subsection{Visual characterisation of the coating}

\subsubsection{Humidity chamber tests}

The coating resistance of a humid atmosphere on unphosphated and phosphated samples were carried out. After exposure to humid conditions, a change in the appearance of the coating surface was not noticed (see Figure 4). The plates tested in the humidity chamber for a period of 10 days did not exhibit any rusting or blistering. Likewise, no traces of corrosive products, cracking or peeling of the coating were found on the surfaces.

\subsubsection{Salt chamber tests}

The coating resistance of the sea atmosphere on unphosphated and phosphated samples were carried out. After exposure to corrosive conditions, a change in the appearance of the coating surface was noticed. A salt spray test was performed on the scribed coatings up to 10 days. It can be seen from Figure 5 that the corrosive electrolyte reached the interface of neat epoxy/metal and resulted in the creation of blisters. The diffusion of the saline solution into the epoxy coating and steel substrate interface is obvious on this sample. This means that the diffused electrolyte could deteriorate the interfacial adhesion bonds and increase the coating delamination distance (Ramezanzadeh et all., 2019).

\subsubsection{Resisting test in salt (sea) water}

The coating resistance of sea water on unphosphated and phosphated samples have been carried out. After exposure to sea corrosive conditions, a change in the ap-

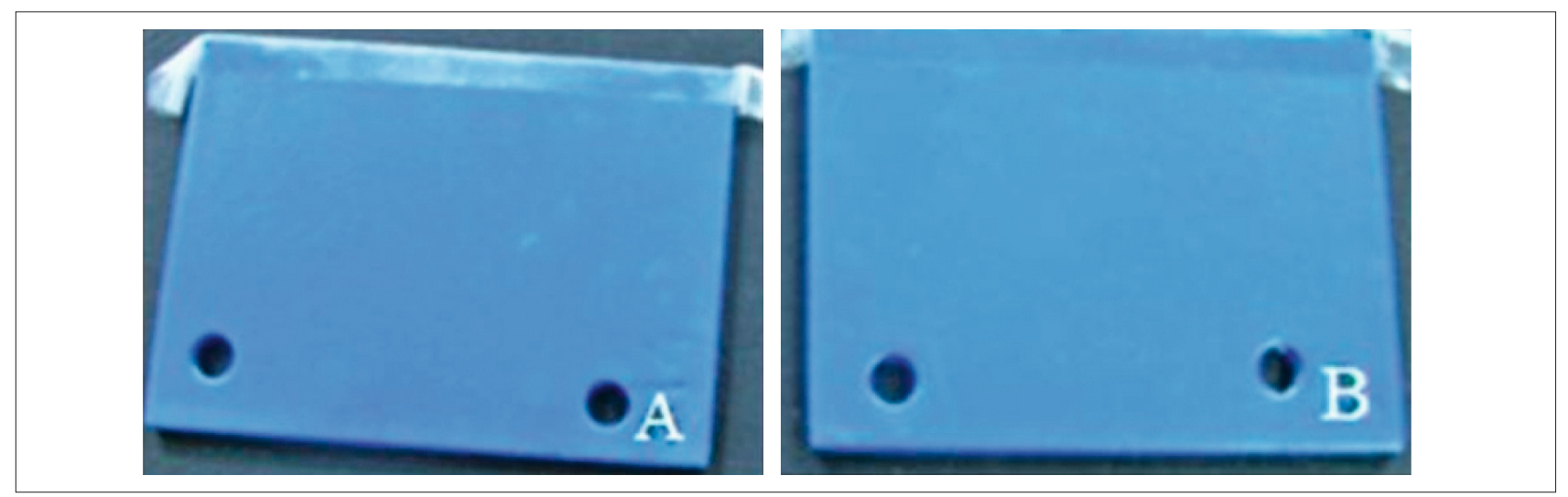

Figure 4: Samples after 240 h of exposure in a humid chamber: A) unphosphated sample; B) phosphated sample 


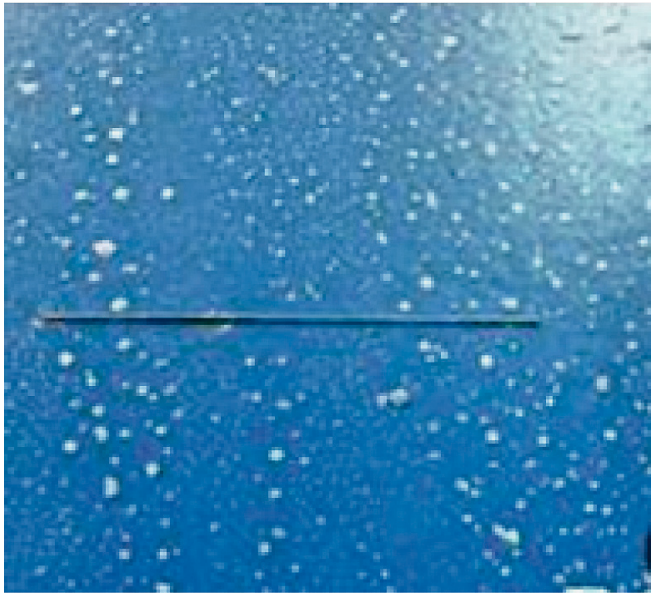

Figure 5: Samples after 240 h of exposure in a salt chamber phosphated sample phosphatizing process. Theoretically, if the hardness of a coating is decreased, then the coating will not improve wear resistance and tear.

\subsubsection{Coating gloss measurement}

The results of gloss are shown at Table 4. In the case of initial samples and samples which were exposed to corrosive conditions, the value of gloss has not change significantly. However, the gloss degrees of coating had a lower or slightly higher value of ten gloss units which included that the coating has a low gloss and it is matte.

\subsubsection{Pull-off Adhesion Test}

The values of adhesion strength are provided in Table $\mathbf{5}$, and it shows the maximum tensile force required for

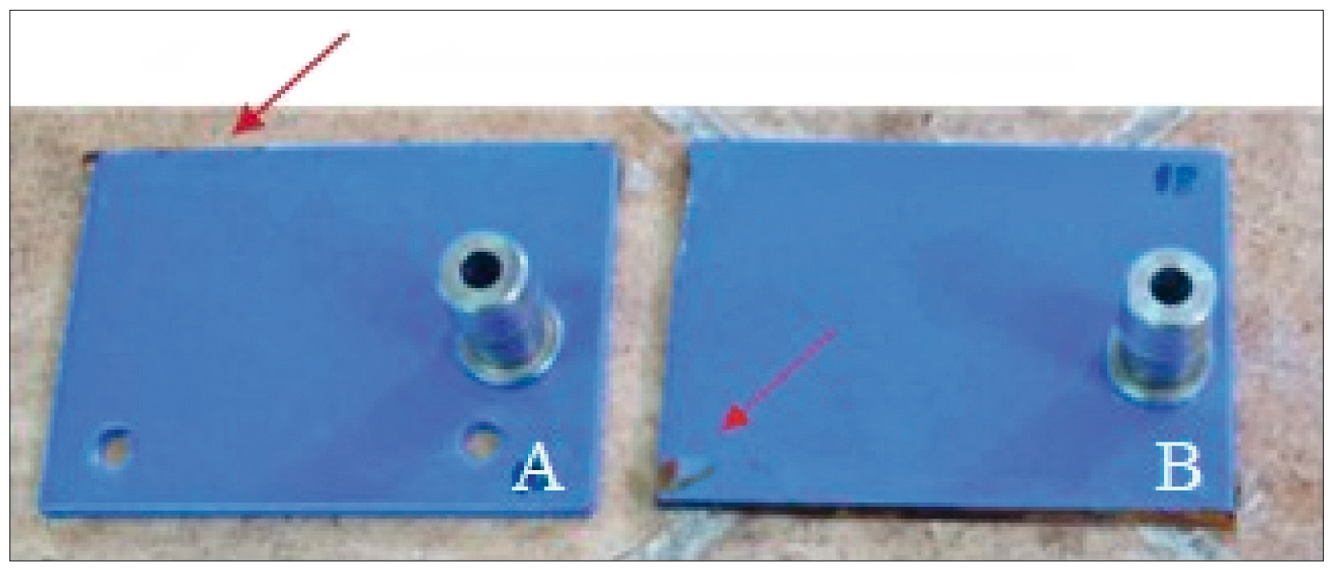

Figure 6: Samples after $240 \mathrm{~h}$ of exposure in a sea water A) unphosphated sample; B) phosphated sample

pearance of the coating surface was noticed. Figure 6 shows minor damage to the protective coating and slight corrosion of the sample at the sites of damage to the coating. However, the plates tested in the salt (sea) water for a period of 10 days exhibited rusting of the undercoated surface. Corrosion appeared only at the edges of the sample.

\subsection{Physical characterisation of the coating}

\subsubsection{Coating hardness measurement}

The results of hardness are shown at Table 3. It can be clearly seen that the unphosphated samples revealed a higher hardness value than phosphate samples. A lower value of phosphate samples might be attributed to the separation. The force to separate the protective coating is higher in the phosphated initial sample than the unphosphated initial sample (see Table 5). The phosphated samples have a lower value of Pull off adhesion test than the unphosphated samples in a salt chamber with high humidity. Phosphated samples which were immersed in sea water show a complete separation of the coating (see Table 5). The value of the Pull off adhesion test shows how the method of sample preparation affects the adhesion of the protective coating to the metal surface of the sample. All samples were not satisfied EN ISO 4624:206 because of the low adhesion between the metal surface and the organic coating.

The samples which were immersed in seawater have a very low value of adhesion strength between the epoxy

Table 3: Hardness of the unphosphated and phosphated samples

\begin{tabular}{|c|c|c|c|c|c|c|c|c|}
\hline \multirow{4}{*}{ pencile } & \multicolumn{4}{|c|}{ unphosphated samples } & \multicolumn{4}{|c|}{ phosphated samples } \\
\hline & \multirow{2}{*}{ initial sample } & \multicolumn{2}{|l|}{ chamber } & \multirow{2}{*}{$\begin{array}{l}\text { immersed in sea } \\
\text { water }\end{array}$} & \multirow{2}{*}{ initial sample } & \multicolumn{2}{|l|}{ chamber } & \multirow{2}{*}{$\begin{array}{l}\text { immersed in sea } \\
\text { water }\end{array}$} \\
\hline & & humidity & salt & & & humidity & salt & \\
\hline & HB & HB & HB & HB & $6 \mathrm{~B}$ & $6 \mathrm{~B}$ & $6 \mathrm{~B}$ & $6 \mathrm{~B}$ \\
\hline
\end{tabular}


Table 4: Gloss of the unphosphated and phosphated samples

\begin{tabular}{|c|c|c|c|c|c|c|c|c|}
\hline \multirow{3}{*}{$\begin{array}{l}\text { angle of light } \\
\text { [GU] }\end{array}$} & \multicolumn{4}{|c|}{ unphosphated samples } & \multicolumn{4}{|c|}{ phosphated samples } \\
\hline & \multirow{2}{*}{ initial sample } & \multicolumn{2}{|l|}{ chamber } & \multirow{2}{*}{$\begin{array}{l}\text { immersed in sea } \\
\text { water }\end{array}$} & \multirow{2}{*}{ initial sample } & \multicolumn{2}{|l|}{ chamber } & \multirow{2}{*}{$\begin{array}{l}\text { immersed in sea } \\
\text { water }\end{array}$} \\
\hline & & humidity & salt & & & humidity & salt & \\
\hline $20^{\circ}$ & 2.3 & 2.7 & 3.0 & 2.4 & 1.8 & 2.3 & 3.0 & 2.8 \\
\hline $60^{\circ}$ & 11.8 & 14.1 & 15.2 & 12.8 & 10.2 & 12.9 & 15.2 & 13.4 \\
\hline $85^{\circ}$ & 6.0 & 4.8 & 9.5 & 5.5 & 3.7 & 7.1 & 9.5 & 5.0 \\
\hline
\end{tabular}

Table 5: Pull off adhesion strength of unphosphated and phosphated samples

\begin{tabular}{|c|c|c|c|c|c|c|c|c|}
\hline \multirow{4}{*}{$\begin{array}{l}\text { force } \\
\text { [MPa] }\end{array}$} & \multicolumn{4}{|c|}{ unphosphated samples } & \multicolumn{4}{|c|}{ phosphated samples } \\
\hline & \multirow{2}{*}{ initial sample } & \multicolumn{2}{|l|}{ chamber } & \multirow{2}{*}{$\begin{array}{l}\text { immersed in sea } \\
\text { water }\end{array}$} & \multirow{2}{*}{ initial sample } & \multicolumn{2}{|l|}{ chamber } & \multirow{2}{*}{$\begin{array}{l}\text { immersed in sea } \\
\text { water }\end{array}$} \\
\hline & & humidity & salt & & & humidity & salt & \\
\hline & 3.9 & 4.33 & 3.69 & 3.63 & 5.03 & 3.04 & 2.78 & 0.38 \\
\hline
\end{tabular}

coating and the substrate (see Table 5) and this shows us that the coating has completely detached. This is indicative of very poor barrier protection.

\section{Conclusions}

This paper studied the effects of the phosphating process on the non-alloy steel surface and adhesion with an epoxy coating. An analysis of the surface morphology revealed that unphosphated samples presented a relatively smoother morphology and the surface qualities of a zinc phosphate coat show good surface qualities without defects. The results show that the initial sample with phosphating surface had better force of Pull off adhesion than the initial unphosphated sample. However, after exposure of the samples to the humid chamber conditions, all samples showed a good corrosion resistance without corrosion products. Corrosion products were observed after exposure of the samples to sea water and a salt chamber. The glosses of testing plates are not significantly changeable after exposure to corrosive conditions. The hardness results illustrated that unphosphated samples have a medium hard coating and samples with phosphates have soft coatings. Hardness does not change after corrosive conditions.

\section{Acknowledgement}

Investigations were performed within the research topic "Development of anti-corrosion protection system for multipurpose pipe use" (Grant number: KK.01. 1.1.07.0045). This work was supported by the European Regional Development Fund under the Operational Program Competitiveness and Cohesion 2014-2020.

\section{References}

Alvarado-Macías, G., Fuentes-Aceituno, J.C., Salinas-Rodríguez, A. and Rodríguez-Varela, F.J. (2013): Understanding the Nature of the Manganese Hot Dip Phosphatizing
Process of Steel. Journal of the Mexican Chemical Society, 57, 328-336.

Bajat, J.B., Mišković-Stanković, V.B., Popić J.P. and Dražić, D. M. (2008): Adhesion characteristics and corrosion stability of epoxy coatings electrodeposited on phosphate hot-dip galvanized steel. Progress in Organic Coating, 63, 201-208.

Dagdag, O., El Harfi, A., El Gana, L., Hlimi, Z., Erramli, H., Hamed. O., Jodeh, S. (2018): The Role of Zinc Phosphate Pigment in the Anticorrosion Properties of Bisphenol A Diglycidyl Ether-Polyaminoamide Coating for Aluminum Alloy AA2024-T3. Jornual of Bio- and Tribo- Corrosion, 5,7.

Finšar, M. and Jackson, J. (2014): Application of corrosion inhibitors for steels in acidic media for the oil and gas industry: A review. Corrosion Science, 86, 17-41.

Gang, L., Wanger, S., Yanrong, C. and Shili, Z. (1997): Quick organic phosphating at room temperature. Metal Finishing, 95, 54,56-57.

Hiromoto S. (2015): 3-Chemical solution deposition of hydroxyapatite and octacalcium phosphate coating for magnesium and its alloys to improve biocompatibility. Woodhead Publishing Series in Biomaterials, 2, 59-80.

Jegannathana, S., Sankara Narayanan, T.S.N., Ravichandran, K., Rajeswar, S. (2006): Formation of zinc phosphate coating by anodic electrochemical treatment. Surface \& Coatings Technology, 200, 6014-6020.

Jiang, C. and Cheng, X (2019): Anti-corrosion zinc phosphate coating on building steel via a facile one-step brushing method. Electrochemistry Communications, 109, 106596.

Khodaei, P., Shabani-Nooshabadi, M and Behpour, M. (2019): Epoxy-Based nanocomposite coating reinforced by a zeolite complex: Its anticorrosion properties on mild steel in $3.5 \mathrm{wt} \% \mathrm{NaCl}$ media. Progress in organic Coatings, 136, $105-254$

Mei, Y., Xu, J., Jiang, L. and Tan Q. (2019): Enhancing corrosion resistance of epoxy coating on steel reinforcement by aminobenzoate intercalated layered double hydroxides. Progress in Organic Coating, 134, 288-296.

Ming-Zhe, B., Zhong-Xia, Li., Ting-Ting, W., Pei-Chung, W. (2013): A new phosphate pretreatment process for adhe- 
sive bonding of magnesium AZ31 sheets. Journal of Coatings Technology and Research, 10, 347-359.

Morozov, Y., Calado, L.M., Shakoor, R.A., Raj, Kahraman, R., Taryba, M.G. and Montemor, M.F. (2019): Epoxy coatings modified with a new cerium phosphate inhibitor for smart corrosion protection of steel. Corrosion Science, 159, 108-128.

Naderi, R. and Attar, M.M. (2009): The inhibitive performance of polyphosphate-based anticorrosion pigments using electrochemical techniques. Dyes and Pigments, 80, 349-354.

Naeem, M., Shafiq, M., Zaka-ul-Islamc, M., Bashir, M.I., DíazGuillénd, J.C., Lopez-Badilloe, C.M.and Zakaullah, M. (2017): Novel duplex cathodic cage plasma nitriding of nonalloyed steel using aluminum and austenite steel cathodic cages. Journal of Alloys and Compounds, 721, 307-311.

Rahmania, P., Shojaeia, A. and Tavandashti, N.P. (2020): Nanodiamond loaded with corrosion inhibitor as efficient nanocarrier to improve anticorrosion behavior of epoxy coating. Journal of Industrial and Engineering Chemistry, 83, 153-163.

Ramezanzadeh, M., Ghasem, B. and Ramezanzadeh, B. (2019): Development of a nanostructured Ce(III)-Pr(III) film for excellently corrosion resistance improvement of epoxy/polyamide coating on carbon steel. Journal of Alloys and Compounds, 792, 375-388.

Ramezanzadeh, M., Ramezanzadeh, B., Sari, M.G. and Saeb, M.R. (2020): Corrosion resistance of epoxy coating on mild steel through polyamidoamine dendrimer-covalently functionalized graphene oxide nanosheets. Journal of Industrial and Engineering Chemistry, 82, 290-302.

Reza Saeb M., Bakhshandeh E., Ali Khonakdar H., Mader E., Scheffler C., Heinrich G. (2013): Cure Kinetics of Epoxy Nanocomposites Affected by MWCNTs Functionalization: A Review. The Scientific Worl Journal, 703708.

Ubong, M.E. and Mazen, M.K. (2014): Corrosion protection of non-alloyed AIAI 316L concrete steel metalgrade in aqueous $\mathrm{H}_{2} \mathrm{SO}_{4}$ : Electroanalytical and surface analyses with Metiamide. Construction and Building Materials, 68, 285-290.

Wang, M., Wang, J. and Wenbin H. (2020): Preparation and corrosion behavior of Cu-8-HQ@HNTs/epoxy coating. Progress in Organic Coatings, 139, 105-434.

Yongsheng, H., Fuchun, L., En-Hou, H., Saima, A. and Guobao, X. (2013): The mechanism of inhibition by zinc phosphate in an epoxy coating. Corrosion Science, 69, 77-86.

Zang Sheng-lin, Chen Hua-hui, Zahan Xiao-lin, Zhang Mingming (2008): The growth of zinc phosphate coating on 6061-Al alloy. Surface and Coatings Technology, 202, 1674-1680.

Zhang, F., Ju, P., Pan, M., Zhang, D., Yao, D., Li, Gouliang and Li, X. (2018): Self-healing mechanisms in smart protective coatings. Corrosion Science, 144, 74-88.

\section{SAŽETAK}

\section{Utjecaj fosfatnoga sloja na svojstva prianjanja između čelične površine i organskoga premaza}

U ovome radu provedena su ispitivanja nekih fizičko-kemijskih svojstava zaštitne epoksidne prevlake na nelegiranome strukturnom čeliku tipa S235JRG2. To je bitan konstrukcijski materijal čija je upotreba iznimno važna za mnoge proizvode od čelika poput H nosača, I nosača, prijenosnih tornjeva, čeličnih cijevi i slično. Jedna od najčešćih metoda zaštite metala od korozije jesu organski premazi. Ispitana su svojstva: debljina premaza, tvrdoća, sjaj te prionjivost. Nakon izlaganja uzoraka u slanoj i vlažnoj komori te potapanjem u morsku vodu ispitivana su ista svojstva kao i na početnim uzorcima. Dio uzoraka prije nanošenja premaza uronjen je u fosfatnu otopinu kako bi se dodatno ispitali učinci fosfatiranja na svojstva premaza. Nakon izlaganja pločica uvjetima vlažne komore na uzorcima nisu pronađeni tragovi korozijskih produkata, pucanja niti ljuštenja prevlake. Uzorci koji su bili izloženi morskoj vodi i slanoj komori pokazali su manja oštećenja zaštitnoga premaza. Svojstvo prionjivosti ispitano je Pull-off Adhesion testom. Sila Pull-off Adhesion testa pokazuje manje vrijednosti za nefosfatirane uzorke nego za fosfatirane.

\section{Ključne riječi:}

korozija, nelegirani strukturni čelik, proces fosfatiranja, epoksidni premaz

\section{Authors contribution}

Marina Samardžija (PhD candidate, mag. ing. cheming. ing, technical sciences): completed a literature review and was responsible for performing experiments and presentation of the results. She also wrote the first version of the article. Vesna Alar (Full Professor, PhD, technical sciences) reviewed. Also managed the whole process and supervised it from the beginning to the end. Fedor Aljinović (Student, mag. ing. petrol., technical sciences): participated in all laboratory measurements and photographing samples for his Master Thesis. Frankica Kapor (Full Professor, PhD, technical sciences) reviewed, improved, and scientifically edited the paper, especially the introduction. 